\title{
The Influence of Contextual Learning Models and the Cognitive Conflict to Understand Mathematical Concepts and Problems Solving Abilities
}

\author{
$1^{\text {st }}$ Dewi Herawaty \\ Mathematics Education Program, \\ Universitas Bengkulu \\ Bengkulu, Indonesia \\ Corresponding author: \\ dewiherawaty71@gmail.com
}

\author{
$2^{\text {nd }}$ Wahyu Widada \\ Mathematics Education Program, \\ Universitas Bengkulu \\ Bengkulu, Indonesia \\ wahyu.unib@gmail.com
}

\begin{abstract}
The present paper aims to investigate the linear effect of cognitive conflict on the ability of the understanding mathematical concepts through the contextual learning model, and to examine the linear effect of cognitive conflict on the ability of problemsolving through the contextual learning model. The research method is quasi-experiment and applying factorial design $2 \times 2$. Research data were analyzed using covariate analysis. The results of this study are: 1 ) direct effect of cognitive conflict covariate on the mean of comprehension ability concept for students taught by Contextual Learning Model better than Conventional Learning Model; and 2) the direct influence of cognitive conflict covariates on mean Problem-Solving Ability for students taught by Contextual Learning Model is better than Conventional Learning Model.
\end{abstract}

Keywords-Understand Mathematical Concepts, Problem-solving, Contextual Learning, Cognitive conflict

\section{INTRODUCTION}

Experts have always seen the subject matter of mathematics school was still not meaningful for the students [1-3]. One of the reasons is the process of learning mathematics junior high school that was too theoretical, and students learn mechanistic [4-6]. This students' experience impulse a cognitive conflict between their conception and theoretical and highly structuralist mathematical material. In the same way, Susilawati et al. argued that cognitive conflict is the most controversial issue in mathematics (such as geometry) which is the most challenging unit to be taught at all levels of education [7]. Therefore, the quality of mathematics learning has become one of the main challenges and concerns of educators [8].

Cognitive conflicts occur when there is a wide gap between the students' conception that comes from long-term memory and mathematical concepts/principles accepted in the learning process
[1], as the condition of consciousness of an individual who was experiencing an imbalance [9]. Conversely, cognitive conflict can also accelerate the process of conception change from a students' understanding [10]. The findings of Herawaty \& Rusdi concealed the improvement of concept comprehension ability through applying of mathematics learning model based on students' cognitive conflict of the junior high school students (SMP) with the significant index gain of 0,755 [5]. Herawaty \& Rusdi also found that the application of mathematics learning model based on cognitive conflict of junior high school students can improve problem-solving ability significantly with the gain index of 0,500 [5]. Regarding Vygotsky, to achieve an improvement in mathematics' learning, teachers should provide scaffolding assistance based on the student's nearest development zone [11-13]. The aids were a technique that was part of the instructional design. The design of a learning model was an effective way to overcome problems related to the quality of teaching and learning mathematics [8].

The results of Kang's et al. research conveyed that there were statistically significant differences in levels of cognitive conflict by students' logical thinking ability level and field-dependent / field-independent cognitive style [14]. However, the learning approach did not have a statistically significant effect on cognitive conflict. On the other hand, Saritas and Akdemir showed that learning strategies and methods, teacher competence, and motivation or concentration were the three most influential factors that must be taken into consideration in the lesson plan mathematics [8]. Therefore, Kang, et al. suggested that the further investigation should reveal the effect of intervention time on the relationship between cognitive conflict and conceptual change [14]. 
An improvement in conceptual understanding was required in the process of mastering concepts in mathematics. Herawaty \& Rusdi stated that mathematics learning was a process of manipulating conditions that enable learners to carry out logical activities to discover or rediscover mathematical concepts [6]. Because, mathematics was a human activity [20]. Previous study [21] disclosed that mathematics is the reflection of the real world, through an empirical abstraction process. It means that mathematical learning should condition interactive activities between learning components (studentteacher-learning resources), making it easier for students to complete their tasks, and internalize formal mathematical concepts/principles. Students can perform horizontal and vertical mathematical processes with appropriate (through approaches: mechanistic, empirical, structuralist and realistic [15]. The application of the approach was administered through realistic mathematics learning with three main principles namely, rediscovery and progressive mathematization, didactic phenomena, and selfbuilding models [20]. With that principle, students were able to solve mathematical problems more efficiently than through structuralist approaches.

A preliminary finding deduced that the ability to solve mathematical problems was an ability to search for and produce a solution of the mathematical problem with various activities: understanding the given problem; creating mathematical models; solving problems according to the mathematical model made; and interpreting the solutions. Therefore, exploiting the real problem, which is starting-point learning of realistic mathematics based on cognitive conflict, encourages students to solve problems in their way [19].

Realistic mathematics learning is a learning with contextual context. If cognitive conflicts also originated from the basis for determining mathematics learning plans, it would encourage students to construct a concept or rediscover the concept of mathematics [15]. This discourse means that contextual learning concerning cognitive conflict can improve students' ability in understanding mathematical concepts. Kilpatrick et al. [16] states that the ability to understand the concept includes several indicators that can re-state the concepts that have been studied. They are ability to classify objects based on whether fulfilled the requirements that form the concept or not; ability to apply the concept algorithm, able to provide examples and non-examples of concepts that have been studied; ability to present concepts in various forms of representation; ability to relate various concepts (internal and external mathematics); and ability to develop sufficient terms and conditions sufficient a concept.

In implementing mathematics learning should consider the factors of psychological development of students [19], so that students can perform the process of mathematization appropriately. The processes of contextual learning involving student cognitive conflict students were able to achieve the ability to understand the concept and problem solving well [9$10]$.

In this paper was discussed about the influence of the application of contextual learning mathematics model and cognitive conflict to the ability to understand the concept and problem-solving ability of junior high school students.

\section{METHODS}

This research conducted a quasi-experimental approach, with a $2 \times 2$ factorial design. The instrument tested the ability of concept comprehension and problem-solving test skills. The population of this study was the students of the junior high school students (SMP) Kota Bengkulu with the sample was 80 SMP Kota Bengkulu selected by intact group technique.

The instruments of this research were concept comprehension ability test, problem-solving test, while cognitive conflict test was used as the covariate. This study experimented with conventional learning models based on students' cognitive conflict controlled by conventional learning models (syntax: conceptual delivery, sampling, training and ending house assignments). Data on test results were analyzed using inferential statistics of covariance analysis.

\section{RESULTS AND DISCUSSION}

In comprehending learning concept, Bengkulu Junior High School students, who were taught by contextual learning model with cognitive conflict orientation, experienced a significant improvement with the mean gain of pretest score ability of concept comprehension was 69,62 , and standard deviation of post-test score of concept comprehension ability was 9,57 [4]. In addition, the improvement of students' ability in mastering the concept was very high. This implies that convincing students about the application of contextual learning model of students' cognitiveoriented conflict (MPKK) can replace the conventional learning model (MKonv). The average ability of students' understanding of the concept of SMP Kota Bengkulu was shown in Fig. 1. 


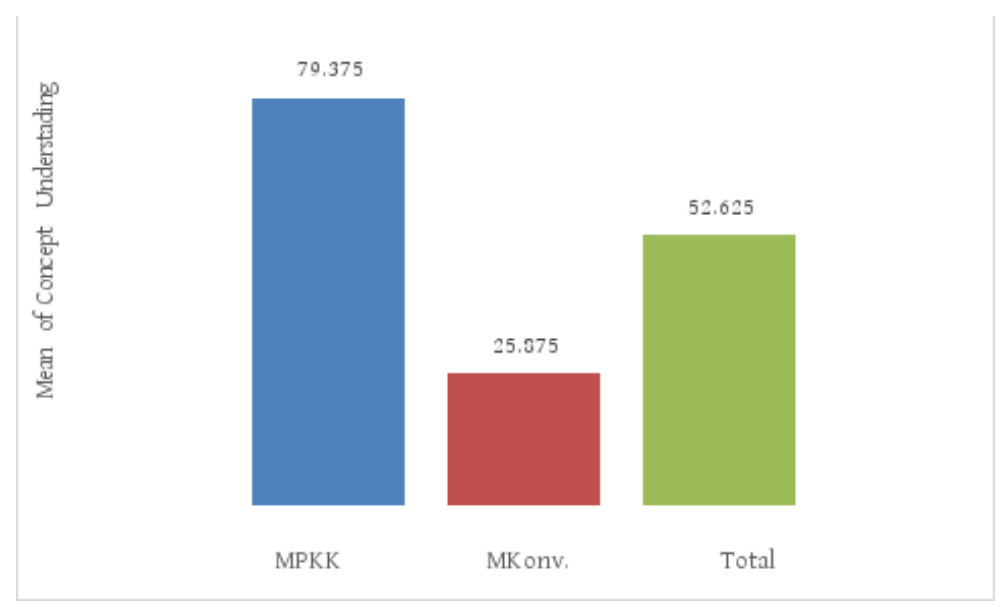

Fig. 1. Mean of Concept Understanding

Based on Fig. 1, the average ability of students' understanding of MPKK concept of 79,375 was much higher than MKonv students. which was only 25,875 . This indicates that the ability to understand students' concepts taught by contextual learning models with cognitive-oriented conflict was better than conventional students. The application of MPKK can overcome students' cognitive conflicts in mathematics learning.Among student cognitive conflicts that can be resolved as the results of Herawaty's initial research [4]. These cognitive conflicts include: " What was $2 / 5$ $+1 / 3$ ? Students answer $3 / 8$, cognitive conflicts occur when students give a reason $(2+1) /(5+3) . "$ "Simplify $3 x-7 y-6 x+3 y-8$ ? Students answered 3x $-7 y-6 x+3 y-8=3 x-6 x-7 y+3 y-8=-3 x-10 y$ - 8. Cognitive conflict occurs when students complete that $-7 y+3 y=-10 y . " "$ Simplify $\left(15 x^{3} y+5 x\right) / 5 x$.

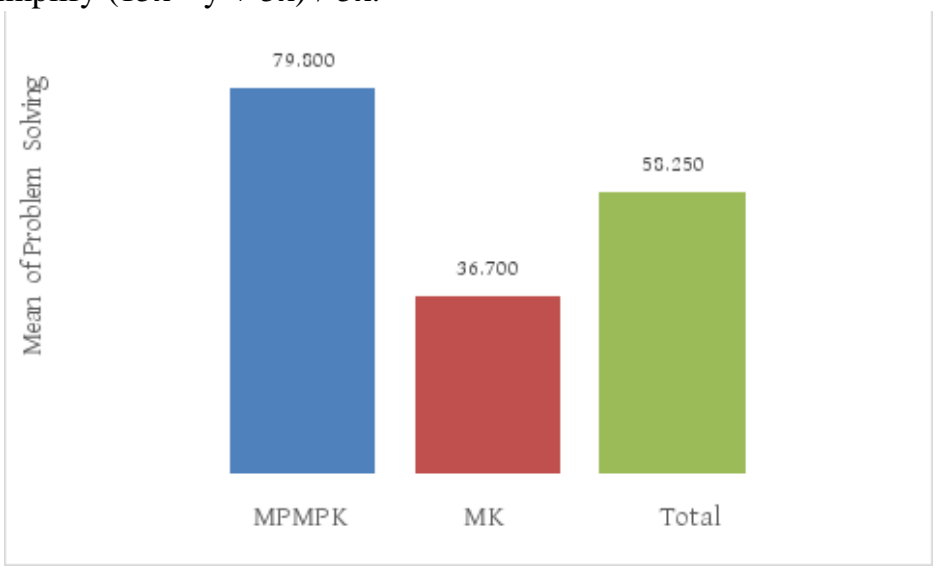

Fig. 2. Average Problem-solving Ability

The data shown in Fig. 2 shows that MPKK has a very positive impact on improving students' mathematics problem-solving abilities of SMP Kota Bengkulu. The mean problem-solving ability of the student of MPKK and student of MK was 79,800 and 36,700 with total average 58,250 . It was the
Students answer $15 \mathrm{x}^{3} \mathrm{y}+1$.Student cognitive conflicts were as follows $\left(15 \mathrm{x}^{3} \mathrm{y}+5 \mathrm{x}\right) / 5 \mathrm{x}=15 \mathrm{x}^{3} \mathrm{y}$ $+1 . "$

In addition to the ability to understand the concept, the problem-solving skills of students of Bengkulu City Junior High School who were taught by contextual learning model based on cognitive conflict experienced an adequate improvement. As Herawaty, et al., data shows that the improvement of the problemsolving ability of Bengkulu Junior High School students after being taught with MPKK was 45,84 with deviation standard 7,23 [4]. The data shows that the students' problem-solving abilities were very high. The results of this study provide an excellent description of the application of MPKK, consider Fig. 2 .

achievement of an excellent learning model implementation. This achievement provides a recommendation that the conventional learning model should be replaced by contextual learning models based on students' cognitive conflict. Conventional learning in question was the delivery of mathematical 
concepts followed by sampling, followed by exercise and ending with house duties.

Covariance analysis as an inferential statistical analysis that gives confidence in the superiority of the contextual learning model. Levene's test in Table 1 test the equality of error variability of conceptual comprehension and mathematical problem-solving abilities.

Table 1 Levene's Test of Equality of Error Variances

\begin{tabular}{lllll}
\hline Dependent Variable & F & df1 & df2 & Sig. \\
\hline Ability to Understand Concepts & 1.608 & 1 & 78 & .165 \\
\hline Problem-solving skill & 0.843 & 1 & 78 & .289 \\
\hline
\end{tabular}

Table 1 shows that the variant error of conceptual comprehension skills for the two sets of learning models (MPKK and MKonv.) was the same, with $\mathrm{F}=$ 1.608 and sig. $=0.165>0.05$. Likewise, the error variant of problem-solving abilities. There was no difference of variance score of the problem-solving ability of math problem between student group of MPKK and MKonv student. Therefore, the ANCOVA may be continued as listed in Table 2 and Table 3.

Table 2 Tests of Between-Subjects Effects

Dependent Variable: Ability to Understand Concepts

\begin{tabular}{lccccc}
\hline Source & $\begin{array}{c}\text { Type III Sum of } \\
\text { Squares }\end{array}$ & df & Mean Square & F & Sig. \\
\hline Corrected Model & $58688.98^{\text {a }}$ & 2 & 29344.49 & 329484 & 0.000 \\
\hline Intercept & 50077.24 & 1 & 50077.24 & 562.274 & 0.000 \\
\hline KK Score & 78956 & 1 & 78956 & 0.887 & 0.158 \\
\hline MP & 41511492 & 1 & 41511492 & 466.097 & 0.000 \\
\hline Error & 6857.77 & 77 & 89.062 & & \\
\hline Total & 287098 & 80 & & & \\
\hline Corrected Total & 65546.75 & 79 & &
\end{tabular}

Based on Table 2, it shows that the corrected model line was $F=29344.49$ with a probability significance of <.05. The test gives a meaning that the built ANCOVA model was correct. Next, we examine the role of cognitive conflict covariates $(=\mathrm{KK})$ in determining the differences in the influence of two models of learning on the ability of conceptual understanding in mathematics learning. Notice Table 2 lines The KK score shows the significance number
$.158>.05$ with $F=0.887$. It means that the role of cognitive conflict covariates was not significant in determining the average difference in the ability to comprehend the concept of the mathematics of students of SMP Kota Bengkulu. Cognitive conflict variables did not significantly influence the mean differences in the ability to understand the concept of two groups of students of MPKK and students of conventional models. 
Notice Table 3 of the MP line shows a significant number of $<.05$ with $F=466.097$, which states that the learning model has a significant influence on conceptual understanding ability. It implies that the influence of contextual learning model based on the cognitive conflict on the ability of students to understand the concept of SMP mathematics better than the conventional learning model when controlled by cognitive conflict covariates. Furthermore, our discussion was the problem-solving ability variable.

Note that Table 4 shows that the influence test between the subjects in the corrected model row of significance was $<.05$ with $\mathrm{F}=133.012$. The corrected model test gives the meaning that the model of the ANCOVA made was correct.

Table 4 Tests of Between-Subjects Effects Dependent Variable: Ability to Solve Mathematical Problems

\begin{tabular}{lccccc}
\hline \multirow{2}{*}{ Source } & $\begin{array}{c}\text { Type III Sum of } \\
\text { Squares }\end{array}$ & df & Mean Square & F & Sig. \\
\hline Corrected Model & 38590963 & 2 & 19295481 & 133.012 & 0.000 \\
\hline Intercept & 28932.789 & 1 & 28932.789 & 199446 & 0.000 \\
\hline KK Score & 38.763 & 1 & 38.763 & 0.267 & 0.342 \\
\hline MP & 14210.053 & 1 & 14210.053 & 97956 & 0.000 \\
\hline Error & 11170.037 & 77 & 145.065 & & \\
\hline Total & 321206 & 80 & & & \\
\hline Corrected Total & 49761 & 79 & &
\end{tabular}

a. R Squared =. 776 (Adjusted R Squared $=.770$ )

The statistical test seen in Table 4 shows that the role of cognitive conflict covariates $(=\mathrm{KK}$, see the line of KK Score) was to determine that cognitive conflicts as covariates can be purified. Table 4 shows $\mathrm{F}=0.267$ with significance number .342> .05, meaning that the role of cognitive conflict covariates was not significant in determining the average difference in the mathematical representation ability of the two groups of students (MPKK and conventional models).Then consider the MP row in Table 4, the significance test of the learning model (MP) shows $F=97.956$ with the significant number <.05. Thus, the influence of contextual learning model based on the cognitive conflict on mathematical problem-solving ability was better than the conventional learning model when controlled by cognitive style covariate. The same thing found Surya et al., that students' ability to solve mathematical problems taught with contextual learning models was higher than students taught by expository [17]. There was an interaction between learning models and early students' math skills to improve students' math problem-solving abilities.

\section{CONCLUSION}

The evidence from this study suggests that the influence of contextual learning model based on the cognitive conflict on mathematical problem-solving ability was better than conventional learning model when controlled by cognitive style covariate. Moreover, the influence of contextual learning model based on the cognitive conflict on the ability of students to understand the concept of mathematics SMP better than conventional learning model when controlled by cognitive conflict covariate. These two conclusions mean that the ability to comprehend the concept and problem solving of math students of Bengkulu City Junior which through contextual learning model of mathematics based on cognitive conflict of students experience a very high increase. Thus, it was suggested to the junior mathematics teacher to turn the conventional learning model with the contextual learning model based on students' cognitive conflict. Finally, we would like to thank the Directorate General for Research and Development, Ministry of Research, Technology and Higher Education of the Republic of Indonesia for the support of this research.

\section{REFERENCES}

[1] D. Herawaty, Rusdi, and E. E. Muchlis, Improved Ability to Understand Concepts and Problem-Solving Abilities through the Application of Realistic Mathematics Learning Model Based on Student Cognitive Conflict, the article was published 
in Proceedings of Jambi International Seminar on Education, April $3^{\text {rd }}-5^{\text {th }} 2016$.

[2] D. Herawaty, and Rusdi, "Increased Capacity of The Understanding of The Concept and The Ability to Solve Problems through the Implementation of the Model of Teaching Mathematics Realistic Based on Cognitive Conflict Students," Infinity, vol. 5 (2), pp. 109-120, 2016.

[3] D. Herawaty, and Rusdi, "Influence of Implementation of Realistic Mathematics Learning Model Based on Student Cognitive Conflict on Ability to Understand Concepts and Problem-Solving Abilities", the article was contained in the Proceedings of Seminar on West BKS Mathematics in Unsri, May $22^{\text {nd }}-24^{\text {th }} 2016$.

[4] W. Widada, "Syntax of Mathematics Learning Model Based on Cognitive Development of Learners," Jurnal Pendidikan Matematika Raflesia, vol. 1 (2), pp. 163-172, 2016.

[5] W. Widada, "Profile of Cognitive Structure of the Students in Understanding the Concept of Real Analysis," Infinity, vol. 5 (2), pp. 83-98, 2016.

[6] W. Widada, and Herawaty, D, "Genetic Decomposition of Mathematics Education Student Reviewed by Model Structure of Knowledge Representation (SRP) and Abstraction Ability (KA) about Real Analysis Concepts" The article is published in Proceedings of the Jambi International Seminar on Education, pp. 656-665, 2006.

[7] Susilawati, W.; D. Suryadi and J. A Dahlan, "The Improvement of Mathematical Spatial Visualization Ability of Student through Cognitive Conflict," IEJME - Mathematics Education, vol.12 (2), pp. 155-166, 2017.

[8] Saritas, T. and O. Akdemir, "Identifying Factors Affecting the Mathematics Achievement of Students for Better Instructiona Design," International Journal of Instructional Technology and Distance Learning, vol. 6. (12) pp. 21-36, 2009.

[9] Asdar, "Cognitive Conflict Strategies in Solving Geometric Problems High School Students in Makassar City", Proceedings of SNMPM Sebelas Maret University, 2012.

[10] Arief, M. A. \& Suyono. Implementation of Cognitive Conflict Strategy in Overcoming Student Misconception on Elementary Electrolyte and Non-Elektrolite Elementary Material Students of SMA X Khadijah Surabaya. Proceedings of the National Seminar on Chemistry Unesa, 2012.

[11] R. I. Arends, Classroom instruction and management, Boston: McGraw-Hill, 1997.

[12] R. I. Arends, Learning to Teach. Fifth Edition. Boston: McGraw-Hill, 2001.

[13] R. E. Slavin, Educational Psychology Theory into Practices.Issue 4. Boston: Allyn and Bacon, 1994.

[14] L. C. Kang, Scharmann, and T. Noh. Reexamining the Role of Cognitive Conflict in Science Concepts, Printed in the Netherlands: Kluwer Academic Publishers. Research in Science Education 34: 71-96, 2004.

[15] Treffers, Realistic Mathematics Education in The Netherlands 1980-1990. "Realistic Mathematics Education in Primary School." Netherlands: Freudenthal Institute, 1991.

[16] Kilpatrick, Swafford, \& Findell, Adding it up: help children learn mathematics. Washington DC: National Academy Press, 2001

[17] E. Surya, \& F. A. Putri, Mukhtar, "Improving Mathematica Problem-Solving Ability and Self-Confidence of High School Students through Contextual Learning Model," Journal on Mathematics Education, vol.8 (1) pp. 85-94, 2017.

[18] Hamalik, Oemar. Teaching and learning process. Jakarta: Bumi Aksara, 2001.

[19] W. Widada, \& D. Herawaty, Realistic Mathematics Learning Based on Bengkulu Ethnomatematics to Increase Cognitive
Level. Proceeding: Bengkulu International Conference on Science and Education, Desember $14^{\text {th }}-15^{\text {th }} 2017$.

[20] K. P. E. Gravemeijer, "Educational Development and Development Research in Mathematics Education," Journal for Research in Mathematics Education, vol. 25(5), pp. 443 471. 1994.

[21] E. von Glasersfeld, "Knowing 1- vithout Metaphysics: Aspects of the Radical Constructivist Position". In F. Steier (Ed.) Research and Reflexity: Toward a Cybernetic/ Social Constructivist Way ofKnowing. London: Sage.1989. 
